\title{
CONFERENCE REVIEWS
}

\section{A Brief Review of the Fifth Off-Campus Library Services Conference, held in Albuquerque, New Mexico, 1992}

\author{
Submitted by Carol Jacob
}

\section{NOW AVAILABLE — FIFTH OFF-CAMPUS SERVICES CONFERENCE PROCEEDINGS.}

The forty papers that make up the Fifth Off-campus Library Services Conference Proceedings were presented at the Offcampus Library Services Conference sponsored by the Central Michigan University Libraries and the Extended Degree Programs of Central Michigan University. The conference was held October 30 - November 1, 1992 in Albuquerque, New Mexico. The papers included in this volume reflect the primary object of the conference: to provide a forum where practitioners involved with off-campus constituents could gather to exchange relevant ideas, concerns and perspectives. Topics include internal and external relationships, program administration, program startup, needs assessments, bibliographic instruction, service in urban settings, promoting services, services in specialized settings, program measurement and evaluation, technology, and research conducted in off-campus libraryservices. It should also be noted that where applicable copies of survey instruments have been included.

The authors contributing to this volume represent a variety of institutions and off campus library delivery systems. For example, Thomas Abbott and Susan Lowe (University of Maine, Augusta) discuss bibliographic instruction using interactive television in the Community college of Maine System. Ellen Waite (Loyola University of Chicago) described what it is like to provide off campus library services to a branch library in Rome, Italy. Rob Morrison (Utah State University) discussed the impact of CD-ROM technology in providing services in rural Utah and Steven Smith and Sharon West (University of Alaska) related similar challenges in Alaska. The role of librarians in faculty development activities were discussed by Julia Daniels and Robert Trullinger (Central Michigan University).

Also included in this volume are papers on the uses of technology by: Herbert White (Indiana University), Pamela Grudzien (Central Michigan University); on interinstitutional planning and cooperation by: Nancy Finney, Kathie Lewis and Connie Fly (California State University), Lynn LaBrake (University of Central Florida), Sharon Stewart (University of Alabama), Ruth Britton (University of Southern California) and David Combe (Ventura County), Donald Wing and Kul Gauri (Macomb Community College); on bibliographic instruction by Susan Cleyle (University of Regina), Linda Fritz (University of Saskatchewan), Monica Hines Collier (Central Michigan University), and Jerilyn Marshal (Northwestern University); on program development by: Gary Pitkin (University of Northern Colorado), Kate Adams, Rebecca Bernthal, Tracy Bicknell and
Debra Pearson (University of Nebraska, Lincoln); on services in an urban setting by Lynn Klekowski and Sharon Mader (DePaul University) and Betty Braaksma (York University); on funding and staffing by: Betty Van Blair (Southwest Baptist University), Rick Bean, Meg Frazier and Bonnielynn Kreiser (DePaul University), Alexander Slade (University of Victoria); on evaluation and effectiveness of service by: Steve Schafer (Athabasca University), Virginia Witucke (Central Michigan University), Raymond Fisher (University of Birmingham), Keith Cottam, William Van Arsdale, Donna Whitson (University of Wyoming); on licensure and accreditation issues by: Edward Garten (University of Dayton), Kenneth Marks and Frances Bradburn (East Carolina University); on needs assessment by: Janice Bradley, Gretta Siegel, and Carol Terry (Washington State University), Stephen McLeod (St. Leo College) on contracts by: Allen Dollerschell (Rochester Community college), Susan Potter and Andrew Scrimgeour(Regis University). In the case of the paper by Susan Potter and Andrew Scrimgeour a reprint of the "Memorandum of Understanding" used at Regis college has been included.

Research in the area of off campus library services was reported by: Marie Kascus (Central Connecticut State University), Karen Jaggers, Eve Tallman and William Waddell (Northern Arizona University), Jack Fritts and Carol Moulden (National-Louis University), Sheila Latham (University of Lethbridge), Martha Hale and Catherine Hoy (Emporia State University), R. Neil Scott, J. Gordon Long and E. Lorene Flanders (Georgia College), Colleen Power (California State University, Chico).

Copies are $\$ 35.00$ per copy from Judith Porter, 207 Park Library, Central Michigan University, Mt. Pleasant, Michigan 48859 or call (517) 774-3500. A limited number of copies of the Fourth Off-Campus Library Conference Proceedings (Charleston, S.C. 1988) are also available for $\$ 35.00$ per copy.

Carol Jacob, Off Campus Library Services, Library at Central Michigan University, Mount Pleasant, Michigan. 